\title{
Between Sharing and Protecting: Public research on genetic resources in the year of the potato
}

\author{
BRAM DE JONGE ${ }^{1}$
}

\begin{abstract}
Countries, companies and farming communities are increasingly involved in issues of sharing and protecting plant genetic resources, (traditional) knowledge and technologies. Intellectual Property Rights and Access and Benefit-Sharing policies currently regulate the transfer and usage of much of this genetic material, information and related production, which is employed in multiple research projects involving public research institutes. Strikingly, not much is known about how these institutes deal with the transfer and usage regulations. And what, furthermore, are their responsibilities while serving a civil society in which there is such a range of diverging interests in and opinions about such regulations? In order to shed more light on these questions, two public research institutes will here be studied, the International Potato Centre in Peru and Wageningen University \& Research Centre in the Netherlands. These institutes are both heavily involved in research into genetic resources, knowledge and technologies related to the potato, and work together with a wide spectrum of stakeholders that have a direct interest in the sharing and/or protection of these resources. The two institutes are continuously weighing up the various stakeholder interests in their attempts to strike a balance between policies geared towards sharing and those aimed at protection. It will be argued that public research institutes must dare to share, and that they need to develop new ways of sharing and protecting in order to adhere to their mission and best serve the public interest.
\end{abstract}

\section{Introduction}

The international landscape with respect to plant genetic resources has changed dramatically over recent decades. Regarded as the "common heritage of mankind" until the $1980 \mathrm{~s},{ }^{2}$ with patents on plants and other living organisms mostly forbidden, ${ }^{3}$ plant genetic resources are now described in terms of "hyperownership", in which "exclusive ownership and restrictions on the sharing of genetic material are the international norm". ${ }^{4}$

Initially, industrialized counties started to expand their Intellectual Property (IP) systems to include new plant varieties and genetic material in search of new markets and to stimulate economic growth. Not much later, however, developing countries became aware of the (potential) value of their plant genetic resources and started to resist the free flow of genetic resources from their territories. With the Agreement on Trade Related Aspects of Intellectual Property Rights (TRIPS) of the World Trade Organization, ${ }^{5}$ the IP concepts of the industrialized countries received global recognition, and in 1992 the Convention on Biological Diversity (CBD) abandoned the common heritage idea, declaring instead that "States have sovereign rights over 
their own biological resources". 6 Significantly, the CBD also demands "the fair and equitable sharing of the benefits arising out of the utilization of genetic resources"7 ie, the providers of plant genetic resources and traditional knowledge should be compensated for their contributions to the products developed by the users of these resources.

Now, Intellectual Property Rights (IPRs) and regulations of Access and BenefitSharing (ABS) set the conditions under which plant genetic material can be accessed and transferred. Clearly, different parties have different interests when it comes to protecting or sharing plant genetic resources and related knowledge and technologies. But what exactly are the interests of public researchers and their institutes in this respect, and what are their responsibilities while doing research for the common good $?^{8}$ These questions will be explored by examining the specific positions and environments of two public research institutes in their work related to the third most important food crop in the world, spotlighted by the UN Food and Agriculture Organisation (FAO) in 2008: The International Year of the Potato.

The public sector plays an important role in the research and development of the potato, in both developed and developing countries. We will focus here on the International Potato Centre (CIP) in Peru, where the potato originated ${ }^{9}$ - and Wageningen University and Research Centre (Wageningen UR) in the Netherlands, the world's foremost supplier of certified seed potatoes. ${ }^{10}$ Working in very different contexts and with a wide, representative range of stakeholders, these two institutes illustrate well the current situation facing public bodies in their exposure to a variety of opinions and pressures related to the sharing and protection of potato genetic resources, (traditional) knowledge and technologies. ${ }^{11}$

\section{Sharing for the common good?}

A good example of the tradition of sharing and collaboration in public science in order to produce benefits for society as a whole is the Consultative Group for International Agricultural Research (CGIAR), of which the International Potato Centre (CIP) in Peru is a member. The CGIAR is an internationally funded, collaborative partnership of fifteen international agricultural centres that aims to achieve sustainable food security and reduce poverty in developing countries. In its mission statement, the CGIAR states that:

The new crop varieties, knowledge and other products resulting from the CGIAR's collaborative research are made widely available to individuals and organizations working for sustainable agricultural development throughout the world. ${ }^{\circledR 2}$

\section{Sharing for the sake of food security}

An important task of CGIAR is to maintain international genebanks to "preserve and make readily available the plant genetic resources that form the basis of food security worldwide". ${ }^{13}$ It is supported in this endeavour by the FAO, which declared the International Year of the Potato to raise awareness of the importance of this crop, and of agriculture in general, in addressing issues of global hunger, poverty and threats to 
the environment. Both organisations, CGIAR and FAO, cherish the rationale that in agriculture no country, or even continent, is self-sufficient in plant genetic resources. ${ }^{14}$ Everybody depends on the genetic diversity found in other countries, and the continuous exchange of plant genetic resources is vital in fighting new pests and feeding a growing world population. The FAO International Treaty on Plant Genetic Resources for Food and Agriculture (ITPGR) aims to support this global exchange with the Multilateral System of Access and Benefit-Sharing, ${ }^{15}$ which establishes a list of major crops and forages - including the potato ${ }^{16}$ - which are freely accessible to member countries under a standard material transfer agreement.

It is in this spirit that CIP director Dr. Anderson sees the job of the institute as to "produce global public goods that will contribute to the alleviation of hunger and poverty [...] and share the benefits of the genetic resources that we conserve". ${ }^{17}$ The primary beneficiaries of this sharing she cites are the broader research community, the national agricultural research systems, and the farmers and farming communities. A complicating factor in this mission, however, is that CIP is based in a country that does not univocally support it.

\section{Peru and the fight against biopiracy}

In contrast to the sharing rationale of CIP and FAO, Peru is primarily interested in the control and protection of its plant genetic resources in order to reap their benefits. Indeed, Peru and her neighbours in the Andes established the Andean Community which designed the Common Regime on Access to Genetic Resources for just this purpose in 1996. Creating a legal framework for the collection of genetic resources in the Andean Region, the Common Regime states that the Andean Community Member Countries "exercise sovereignty over their genetic resources and their by-products and consequently determine the conditions for access to them" aiming to ensure a "just and equitable participation in the benefits of the access". ${ }^{18}$

The central idea is that Peru has much to gain from its genetic resources, the region being a "centre of origin" for many plant and animal species, including the potato, tomato, coca and alpaca. Mrs. Rosell of the National Council of the Environment, the agency responsible for ABS in Peru, expresses the Peruvian argument thus:

If you want to develop an invention and you are using somebody else's screws you pay for the screws, [so] if you are using somebody else's genetic resources why don't you pay for them? ${ }^{19}$

When biological resources or related traditional knowledge is taken and commercialised without permission one often speaks of "biopiracy". For some policymakers in Peru, CIP's genebank collections could be "one of the main sources of 'leakage' of genetic materials". ${ }^{20}$ CIP has indeed been faced with accusations of biopiracy - in respect of which, states a communication officer at CIP, "we have to answer questions on the centre's policies and activities on a regular basis". ${ }^{21}$

\section{A different outlook on genetic resources}

Another group in Peru that follows the sharing and collecting activities of CIP with a critical eye are the farming and indigenous communities in the Andes. Potato crops 
have been cultivated here for more than 8000 years, with some 5000 varieties currently being grown. ${ }^{22}$ The natural characteristics of these potatoes are strongly interwoven with the cultural and spiritual life of the Andean communities. Several initiatives aiming to protect and sustain this natural and cultural diversity have recently been set up, including the Indigenous Coalition Against Biopiracy in the Andes, a Peruvian coalition that made the news in 2007 after sending a letter to the multinational Syngenta protesting against its patent on a genetic method that could be used to stop potatoes from sprouting unless a chemical was applied. The letter expressed concerns that this "terminator technology" threatened the region's biodiversity, cultural traditions and food security. Furthermore, it stated that:

We feel greatly disrespected by corporations [which], by making a
single genetic alteration to a plant, claim private ownership to it as
their invention, despite the fact that these plants are the result of
thousands of years of careful selection and breeding by indigenous
peoples and local communities around the world.

The fight against biopiracy and call for benefit-sharing of the Andean communities is different from that of Peru as a country, however. These communities want to make their own rules, according to their worldviews and traditions, and resisting against all outside, intruding forces. To many Andean communities the Peruvian State is just another one of these forces, along with the international genebanks that come to take their "genetic heritage" without giving anything in return. ${ }^{24}$ According to Dr. Argumedo, associate director of the Association for Nature and Sustainable Development (ANDES), the national and international ABS regulatory system "reduces all things into genes and commercial commodities that then can be traded", which has nothing in common with the way indigenous communities manage their land and resources:

When you don't take into consideration how local people perceive the resources, the way they understand the so-called genes and seeds, you just impose a new paradigm that will only serve the interests of research organizations and corporations. ${ }^{25}$

\section{Competing interests}

So what does - should - CIP do in response to this regional/national and local opposition to its mission to collect and share genetic resources in the name of the common good? In general, the public research sector is far from positive about the current ABS climate and tries to stay away from it. A recent, CBD-linked, report states that "Researchers in both academia and industry express significant concern about the negative impact ABS is having upon basic science and upon traditions of trust and collaboration among scientists". ${ }^{26}$ In the report, one researcher argues that "both academic researchers and companies today are reluctant to access genetic resources overseas for fear of ' ... becoming part of a very dangerous socio-political environment in which anyone can claim they are biopirates at any time". ${ }^{27}$ The report also acknowledges that many academic researchers do not take the CBD seriously, "and while paying lip service prefer in practice to 'ask forgiveness rather than ask permission.' Some see the new obligations as too burdensome and expensive in time and funds". 28 
Indeed, the current situation is far from satisfying. The global exchange of plant genetic resources has decreased dramatically since the ratification of the CBD. ${ }^{29}$ In Peru, the acquisition of new genetic resources "essentially came to a halt in 1994, primarily as a result of the conflicting natures of the international, regional and national laws". ${ }^{30}$ Despite the fact that Peru has ratified the ITPGR, which should ease the way for the collection and exchange of the potato resources, it is still unclear exactly which national regulations apply. ${ }^{31}$ In such a "policy vacuum $[\ldots]$ it is easy for anxiety and suspicion to proliferate", confirm Rosenthal and Katz. ${ }^{32}$ They conclude, however, that researchers should work to overcome this situation and develop effective collaboration:

The research community needs to demonstrate that this work can be done in a flexible and accommodating manner that recognizes the environmental and socioeconomic context in which these organisms exist, or we will lose access to them in the near term through politics, and eventually through extinction.

\section{New ways of sharing for the public interest}

CIP and the broader public research community have a responsibility to work towards a solution of the present situation where fears about the misuse and disagreements about the sharing or protection of genetic material are rife. A first step towards a solution is for research institutes to listen and be open to the opinions of the stakeholders they are working with, or for. Since the mission of CIP is to support developing countries and their farming communities, it would make no sense to simply ignore or dismiss their views. A second step, then, would be to reassess the exact meaning of CIP's tradition of sharing genetic material in the name of the public good, because it has become clear that the free, international exchange of resources that originated in the Peruvian Andes is not necessarily considered to be in the best interest of the country or its indigenous communities. And this is exactly what CIP has been doing in recent years.

When, in 2004, Peru established the National Anti-Biopiracy Commission to develop "actions to identify, prevent and avoid acts of biopiracy with the aim of protecting the interests of the Peruvian State", ${ }^{34}$ CIP became a member; it now helps the Commission in its technical research. With respect to the protection of traditional knowledge and potato resources of small farmers, CIP developed a catalogue of native potato varieties grown by eight farming communities in the Huancavelica region. CIP and the communities, in collaboration with the Peruvian patent office, collected botanical information and traditional knowledge about the varieties, together with details about their genetic make-up and portraits of the families that grow them. ${ }^{35}$ According to one person involved, this initiative has several important benefits, since it is a tool "to hold onto the knowledge, to protect the intellectual property of farmers, and to raise self-esteem of the involved communities: they now manage their own databases". ${ }^{36}$

Another example is the 2005 Repatriation Agreement that CIP signed with the Potato Park, a centre of origin of potato diversity, co-founded by ANDES and managed by 
six Quechua communities, which aims to protect the "collective bio-cultural heritage" of Andean communities, by building upon the practices and traditions of the communities themselves within their natural environment. ${ }^{37}$ The Agreement announces the repatriation of traditional potato varieties in the CIP genebank back to the indigenous communities of the Potato Park. Furthermore, it establishes a collaborative effort to conserve, monitor and develop agricultural biodiversity by linking the in-situ conservation at the Potato Park with the ex-situ conservation practices of CIP. In the Agreement, CIP recognizes the customary rights and responsibilities through which the indigenous communities manage their land and resources, in line with which the centre aims to "Ensure that genetic resources and knowledge remain under the custody of the communities and do not become subject to intellectual property rights in any form". ${ }^{38}$

These examples show that CIP is well aware of the variety of perspectives on the sharing and protection of genetic material. It respects these perspectives and tries, where possible, to help the Peruvian state and farming communities protect their resources against misuse. Furthermore, it continues to find new ways of sharing for the public good - ie, ways of sharing that suit its environment: the centre works together with the Peruvian government and patent office and shares with them its technical expertise, and it collaborates with farming communities and provides them with different products, knowledge and genetic resources. Of course, the centre still aims to collect new potato varieties and facilitate their international exchange for the sake of food security, but it does so within the limits set by its host country and the communities it intends to support. Thus does CIP build a relation of trust - of the type that might well be a prerequisite to overcoming the present impasse in the collection and exchange of plant genetic resources.

\section{Protecting for the common good?}

So far, what has been described is a situation in which a public research institute, whose mission it is to stimulate the free exchange of potato resources for the public interest, finds itself in an environment that does not support that same goal and instead has to deal with the protection of what stakeholders consider to be their genetic resources or heritage. The opposite situation occurs when a public research institute aims to protect certain genetic resources, knowledge and technologies for the common good, but with consequences that can go against this objective - a situation that will be analysed in relation to the potato research at Wageningen University and Research Centre in the Netherlands.

Wageningen UR is a framework of cooperation between a university (Wageningen University), a university of professional education (Van Hall Larenstein), and several specialised research institutes organised under the umbrella of a non-profit, private institute (DLO Foundation). This has created a structure in which education is combined with fundamental, policy-oriented and applied research. Together, the mission of Wageningen UR is "to explore the potential of nature to improve the quality of life". 39 


\section{Public research to support the private sector}

An important reason for Wageningen UR to protect certain resources is that the institute aims to support the Dutch private sector - to assist it in attaining "the most competitive position possible". ${ }^{40}$ The potato sector represents an important part of Dutch agriculture, with an export value of seed potatoes worth $€ 300$ million a year and of starch potatoes and processed products up to $€ 1.5$ billion a year. ${ }^{41}$ Indeed, the Netherlands has become the global market leader in the development of new potato varieties and the export of certified seed potatoes, and has a large share in the export market of potatoes for consumption and processing.

Mr. van Winden of the Dutch Ministry for Agriculture, Nature and Food Quality acknowledges that the Dutch government aims to "create favourable preconditions for the sector" in order to "help the Dutch breeding sector to retain its leading position in potatoes and other crops". ${ }^{42}$ One precondition is to support research and innovation by funding public-private collaborative research projects. An example is the Technological Top Institute Green Genetics (TTI GG), an institute led by the commercial partners which, in close collaboration with public institutes, notably Wageningen UR, has established a strategic research agenda to "develop and apply genetic information for the creation of crops with improved performance and improved quality". ${ }^{43}$ Because the main objective is "to convert knowledge developed in the programme into value for the Dutch economy", ${ }^{44}$ intellectual property protection plays an important role within this research programme. This means, for example, that the public research partners are bound to regulations on confidentiality over research results and only allowed to publish after the valorisation of knowledge has been considered and, if relevant, intellectual property protection applied for. ${ }^{45}$

\section{Valorisation strategies}

According to Prof. Visser, head of Plant Breeding at Wageningen UR, these issues are well organised within the research project and the interests of public researchers secured: Intellectual Property Rights (IPRs) have simply "become part of the game" in public research. ${ }^{46}$ In fact, public funding organisations are not only supporting public-private partnerships, but are also increasingly promoting the application of IPRs in public research itself. Organisations like the Technology Foundation STW and the Netherlands Genomics Initiative (NGI) - both part of the Netherlands Organisation for Scientific Research (NWO) - aim to combine high quality research with its social application, a mission which has resulted in a strong focus on valorisation and an important role for IP policies.

NGI funds the Centre for BioSystems Genomics (CBSG), another public-private partnership in which Wageningen UR collaborates with Dutch industries (through the complete chain of potato breeding and processing). The Centre's aims include unravelling the genetic code of potato plants "to reduce the use of chemical pesticides and improve product quality for consumers and industry". ${ }^{47}$ NGI has set targets for the Centre at 25 patents, 20 licences and 2 spin-off companies by $2012 .^{48}$ Thus NGI aims to go "[from] knowledge to the market: from concept to product or company", in order to "get the most out of genomics". ${ }^{49}$ Indeed, according to one valorisation officer, if a public researcher were to discover a new genetic trait that stimulates 
resistance to an important disease but publish before patenting, the discovery might not be developed further, precisely because it could not be protected in the marketplace and investments recuperated. ${ }^{50}$

But Wageningen UR also has its own reasons to develop an effective valorisation and IP policy. In order to "generate value from knowledge", 51 the institute has established the Wageningen Business Generator (WBG), to "identify promising opportunities and turn them into thriving businesses". 52 According to Wageningen UR's Dr. Louwaars, one reason for the institute to invest in intellectual property strategies is to generate extra income, especially since genomics and biotechnology research is extremely expensive and funding bodies hardly ever finance the total costs of a research project. Other reasons are to maintain a position at the frontier of science through maximising its own freedom to operate, and to remain attractive for market parties and acquire research contracts and partnerships. ${ }^{53}$ In other words, an extensive IP portfolio can both strengthen one's bargaining position in the market place and reduce the possibility of one's research agenda being blocked by the intellectual property rights of others.

\section{Uncertainties}

We conclude that Wageningen UR aims to protect certain resources and research results in order to 1) support the economically important potato sector, 2) meet the terms of funding organisations and stimulate the valorisation of research outcomes, and 3) strengthen its own financial and strategic position so as to perform cuttingedge science. All these reasons are likely to support the public interest. Still, there are several uncertainties about whether the protection of research outcomes in public science $i s$ the best way forward and whether this is, indeed, for the common good.

At the practical level, it is not an easy task to develop an efficient and profitable IP and valorisation strategy. Wageningen UR now has to establish effective methods of identifying and then promoting commercially promising innovations, including the negotiation of corporate IP contracts. This is a process only complicated by the disinterest in intellectual property issues of many public researchers. According to one researcher at Wageningen UR, intellectual property issues are often very complex and fall completely outside the expertise of most researchers, for which reason many consider dealing with them a trying business. ${ }^{54}$ Another practical point of uncertainty is a doubt about whether IPRs will, in fact, generate much income, especially when the costs of filing a patent are known to be high. One study shows that American universities received, on average, only $0.56 \%$ of total revenues from their patenting strategy in $2003 .^{55}$

At the theoretical level, issues range from philosophical questions about the patentability of living matter ${ }^{56}$ to reflections on the possible incompatibilities between the call for valorisation and the traditions of disinterestedness and independence in public science. ${ }^{57}$ The biggest worry, however, is that IPRs go against the public interest because they can block access to research tools and results and thereby hamper innovation instead of stimulating it. ${ }^{58}$ Agricultural research can be particularly vulnerable to this because much research is "based on pre-existing plant 
material, and each incremental improvement now brings with it a number of IP and germplasm constraints that have accumulated in the plant material". ${ }^{59}$ The fear is that developing countries especially will suffer from this.

\section{Research for development}

This issue was the central theme of a one-day symposium at Wageningen UR organised in the context of the International Year of the Potato. The symposium built upon a recent statement by Mr. Koenders, Minister for Development Cooperation:

I would also urge Dutch universities and research institutes to adopt institutional IP policies that take account not only of valorisation of knowledge and incentives for researchers, but also the importance of access to knowledge and freedom to operate for development purposes. ${ }^{60}$

The key issue is twofold. On the one hand, an increased focus on valorisation can steer public research towards profitable research areas like commercial farming away, that is, from the low- or no-profit crops of small farmers, especially in developing countries. On the other hand, IPRs can block access to biotechnologies and related knowledge, especially for parties that have no resources to negotiate and pay for access licences and patent royalties. During the Wageningen UR symposium, CIP biotechnology advisor Dr. Ghislain confirmed that his centre experiences severe difficulties with accessing IP-protected knowledge and technologies:

The transfer of proprietary biotechnology from the private sector [...] has never been so difficult, not to say impossible, [...] the public sector is still transferring proprietary technology but with increasing difficulties and restrictions ${ }^{6}$

The rector of Wageningen UR, Prof. Kropff, agreed at the symposium that the institute has to take these issues into account because it wants to support the Millennium Development Goals - and thus to make knowledge and technology available for developing countries - but it also aims to generate income and spin-off companies by applying intellectual property rights. A possible strategy in this respect is one applied in 1996, when researchers from Wageningen UR transferred a patent on a molecular technology to modify cassava to a Dutch company through a Humanitarian Use License that ensured the royalty-free use of the technology for food security goals and local use, but not for the world trade in starch. ${ }^{62}$ One complicating factor here is that Wageningen UR shares most of its intellectual property with other research partners, so "the question how to transfer that IP and make it available for developing countries is something that we have to discuss together with those partners".63

\section{New ways of protecting for the public interest}

So, the main question is how public research institutes like Wageningen UR can balance protection with sharing for the common good. Protecting public research outcomes with still stronger and broader IPRs is not likely to be in the public interest, but neither is the rejection of any form of IP protection in public research. The real challenge lies in deciding on the optimum form and amount of IP protection in order 
to "support innovation for the benefit of society", ${ }^{64}$ which is the ultimate goal of IP regimes and the mission of most public research institutes.

In order to reach that balance, according to the International Expert Group on Biotechnology, Innovation and Intellectual Property (IEGBIIP), public research institutes need to turn away from two "faulty assumptions" that currently characterise IP policies generally, namely "that since some intellectual property is good, more is better; and that IP is about controlling knowledge rather than sharing it" ${ }^{65}$ Rather, IP protection should be seen for what it is:

[...] a cog in a large system of innovation that brings researchers,
universities, companies, government, non-governmental
organisations, patients and technology users together to create,
improve, disseminate and use new practical knowledge. 6

IEGBIIP pleads for a new era of intellectual property protection, which "stresses sharing and collaboration instead of increased protection, leading not only to greater levels of innovation, but better access to new products and services". ${ }^{67}$

A first step towards such an era is to stop putting IPRs on a pedestal, as if, for example, the amount of patents acquired says something about the success of a research project. Instead, funding organisations and public research institutes should look for ways of measuring success that relate directly to their public missions - eg, the number of partnerships and research platforms in which the institute participates, the number of trainees, or the scope of dissemination of research results. From an ethical perspective, public research projects should surely be judged by their success in enabling global access to their research results for development purposes.

A second step, of course, is to start formulating IP policies that stimulate collaboration and knowledge sharing for the benefit of society. Wageningen UR is now in the process of developing an IP policy and should look seriously at promising examples in this regard. One such is the white paper issued by a group of universities in the US, ${ }^{68}$ which offers guidelines for universities in formulating license agreements with the private sector that facilitate the broad dissemination of university-generated technologies and allow the scientific community to conduct further research and development of the licensed material. Another example is the Public Intellectual Property Resource for Agriculture initiative, which brings together public sector intellectual property to make agricultural technologies available to innovators around the world. ${ }^{69}$

Wageningen UR has also built itself experience in this matter, however, as with the cassava license referred to above, the question is whether and how this strategy can be turned into general policy. Given that Wageningen UR shares much of its IP with other parties, decisions have to be negotiated. A complicating factor in such negotiations, according to Prof. Visser, is that "if you want to have a say in the IP management of a research project, you have to bring something to the table". ${ }^{70}$ This means, for example, that the public partner has to share in the costs of the research project and its IP strategy, which can be financially problematic for cash-strapped 
public institutions. Wageningen UR should, therefore, initiate serious consultation with its research partners and the Dutch government and public funding organisations, in order to reflect on the desired role of IPRs within public research and work together towards new ways of protecting for the common good.

\section{Between sharing and protecting}

Manifestly, the two public research institutes described operate in a complex environment in which different stakeholders - including the institutes themselves have diverging interests in, and opinions about the sharing and protection of plant genetic resources, related knowledge and technologies. For public research institutes charged with serving the public interest, finding the right balance between sharing and protection is no easy task. In the case of CIP, we have an institute which is primarily concerned with the global exchange of plant genetic resources for the sake of food security but situated in a country that does not consider this sharing rationale to be in its primary interest and where concerns about biopiracy are widespread. To simply reject the Peruvian position as counterproductive because Peru is as dependent on foreign plant genetic resources as any other country would be to miss the point. Mrs. Rosell agrees that we all have benefited from the former tradition of free exchange of plant genetic resources, but asserts that "there are some that have benefited more" and now "we want some compensation for the contributions of Peru". ${ }^{71}$ It is not that the benefits of sharing go unacknowledged, but rather that the benefits of protecting may appear to be more substantial (to say nothing of perceived historical injustices).

\section{Self-interest}

It is not only gene-rich countries and communities that choose to protect their genetic material in order to reap the benefits and preclude misappropriation. Industrialized countries, biotechnology companies and public research institutes set up IP policies for similar reasons. The basic rationale that underlies most decisions about sharing or protecting is rather simple: sharing carries more risk, is more insecure. Protection is a defensive stance in which one holds on to and enjoys the benefits from what one has; sharing gives away the competitive advantage of exclusive access for the promise of benefits that are often indirect and insecure, because they depend on the actions of others, who may even misuse or misappropriate what is shared.

An example of the academic dimension of the defensive stance can be described with respect to the Potato Genome Sequencing Consortium (PGSC), coordinated by Wageningen UR. The Consortium aims to sequence the complete potato genome by the end of 2010 in order to "meet the world's food needs in the future" ${ }^{72}$ The project is based on "an open information policy where all data is intended to be freely shared between the partners and the scientific community at large". ${ }^{73}$ In such "community resource" projects, however, scientists might be data users or data producers (or both). The former are interested in rapid access to all data while the later can be reluctant to put their genome sequences into an open database straightaway, fearing that others might use the data in publications before the providers themselves have been able to publish and take credit for their work. ${ }^{74}$ 
In 2003, the Wellcome Trust organised a meeting to discuss this issue, which concluded that the "scientific community will best be served if the results [...] are made immediately available for free and unrestricted use," but continued by stating that "it is crucial that the scientific community recognizes and respects the important contribution made by the scientists", ${ }^{75}$ and going on to urge resource users to acknowledge resource producers and cite data sources. Nevertheless - and importantly, I would suggest - the Trust does come with the additional recommendation:

Resource producers should recognize that even if the resource is occasionally used in ways that violate normal standards of scientific etiquette, this is a necessary risk set against the considerable benefits of immediate data release. ${ }^{76}$

\section{Dare to share}

In order to promote sharing as beneficial to the wider community, academics and the academic community are urged to take the risks of sharing. A recent CBD-linked report similarly recommends gene-rich countries and communities not to "sacrifice the invaluable benefits of scientific collaboration [...] out of fear that commercial research cannot be adequately regulated or monitored". ${ }^{77}$ In this context, Safrin points out that developing countries have repeatedly maintained that they would "completely open up access to raw genetic material within their borders [...] if developed countries would place improved genetic material in the public domain". ${ }^{78}$

The overall message of these examples is that it takes something extra to share. The benefits and risks of sharing depend on the actions of others, like their willingness to reciprocate and potential to misuse resources. Sharing means vulnerability. But as the benefits of sharing for the wider community can be considerable, these risks and uncertainties should sometimes be set aside. For research institutes whose mission it is to serve the public interest, this is exactly what they should do. Even while they are continuously searching for the best balance between sharing and protecting plant resources, knowledge and technologies, the contemporary situation demands that research institutes reconsider their policies in order to develop new ways of sharing and protecting - for the common good. In a time of hyperownership, public research institutes have a responsibility to show that the current trend of enclosure and protection of genetic material and knowledge can be overcome by daring to share.

\section{Conclusion}

CIP and Wageningen UR are situated in totally different environments, but both interact with a range of stakeholders that have strong and diverging interests in respect of the sharing and protection of the plant genetic resources, knowledge and technologies the institutes work with. While CIP aims to promote the sharing of potato genetic resources throughout the world for the sake of food security, Wageningen UR is concerned with supporting the Dutch potato sector. CIP is also, however, confronted with a society that is deeply ambivalent about the sharing goal and where concerns for biopiracy proliferate, while Wageningen UR has to ensure that its IP and valorisation strategies do not impede its research for development 
goals. It is clear that public research institutes have a difficult job in balancing their sharing/protecting policies in order to cope with the variety of interests involved.

This task is, furthermore, set against the current situation of hyperownership, in which countries, companies and indigenous communities alike fear for their resources and aim to protect them. Public institutes like CIP and Wageningen UR thus have to collaborate with stakeholders from the starting point of respecting their protectionist interests. In order to work towards new ways of operating that support both their direct environment and the global community, however, these and other public research institutes should pay attention not to overly protect their own resources. The negative dynamics of hyperownership can only be overcome if all parties take reciprocal steps towards a more open system, ${ }^{79}$ but someone has to take the first step. In order to fulfil their mission and serve the common good, public research institutes should not hesitate to take that first step and dare to share.

\section{Acknowledgements}

The author is based at Wageningen UR. This article is the result of a research project of the Centre for Society and Genomics in The Netherlands, funded by the Netherlands Genomics Initiative. A travelling grant was provided by the Netherlands Organisation for Scientific Research (NWO). I am most grateful to all the people I have interviewed for their time and contribution, and to Niels Louwaars, Michiel Korthals and Andy Hilton for their valuable comments on earlier versions of this article. All the views presented as well as the mistakes remain my own.

\footnotetext{
${ }^{1}$ Applied Philosophy, Wageningen UR, Wageningen, the Netherlands, and the Centre for Society \& Genomics, Radboud University Nijmegen, Nijmegen, the Netherlands bram.dejonge@wur.nl ${ }^{2}$ FAO. 1983. International Undertaking on Plant Genetic Resources. Resolution 8/83. Food and Agriculture Organization of the United Nations.

${ }^{3}$ N.P. Louwaars et al. 2005. Impacts of strengthened intellectual property rights on the plant breeding industry in developing countries: a synthesis of five case studies. Wageningen: CGN.

${ }^{4} \mathrm{~S}$. Safrin. Hyperownership in a time of biotechnological promise: The international conflict to control the building blocks of life. The American Journal of International Law 2004; 98: 641-685.

${ }^{5}$ WTO. 1994. Agreement on Trade-Related Aspects of Intellectual Property Rights. Marrakesh, 15 April 1994.

${ }^{6}$ UNEP. 1992. Convention on Biological Diversity. Rio de Janeiro, 5 June 1992: Preamble

${ }^{7}$ UNEP. 1992. Convention on Biological Diversity. Rio de Janeiro, 5 June 1992: Article 1

${ }^{8}$ The terms "common good" and "public interest" are not strictly defined here, being used to refer to the general notion that public research institutes should work for the benefit of society as a whole. ${ }^{9}$ D.M. Spooner et al. A single domestication for potato based on multilocus amplified fragment length polymorphism genotyping. Proceedings of the National Academy of Sciences of the United States of America 2005; 102: 14694-14699.

${ }^{10}$ FAOSTAT http://faostat.fao.org (consulted 3 October 2008)

${ }^{11}$ In addition to policy documents, news reports and scientific literature, input for this analysis comes from an international conference organised in Wageningen on 11 April 2008, together with a total of 33 interviews conducted with individuals from research institutes and other (non-)governmental organisations in Peru and the Netherlands between April 2007 and September 2008. (Names and affiliations of the interviewees are included if permission was granted; otherwise only the affiliation is mentioned.)

${ }^{12}$ CGIAR http://www.cgiar.org (consulted 03-10-2008)
} 
${ }^{13}$ Ibid

${ }^{14}$ GFAR and IPGRI. 2000. Strengthening Partnerships in Agricultural Research for Development in the Context of Globalization. Rome: GFAR \& IPGRI.

${ }^{15}$ FAO. 2001. International Treaty on Plant Genetic Resources for Food and Agriculture. FAO

Document CGRFA/EX-6/01/2.

${ }^{16}$ With the exemption of one species, Solanum phureja.

${ }^{17}$ P.K. Anderson. 2003. Case Study: Genetic Resource Conservation and Benefit Sharing at the International Potato Center. Conference presentation, 16 October 2003. Available at:

http://www.syngentafoundation.com/symposium_benefit_sharing_genetic_resource_conservation.htm

${ }_{18}$ Andean Community. 1996. Common Regime on Access to Genetic Resources. Decision 391: Articles $5 \& 11$

${ }^{19}$ Personal communication, 2007

${ }^{20}$ C.M. Correa. The Access Regime and the Implementation of the Fao International Treaty on Plant Genetic Resources for Food and Agriculture in the Andean Group Countries. Journal of World Intellectual Property 2003; 6: 795-806, p.804.

${ }^{21}$ Personal communication, 2007. Eg, questions were raised when traditional Peruvian varieties of Yacon from the CIP genebank ended up in Japan, where new commercial varieties were being developed; GRAIN. 2001. Unethical distribution to Japan of Yacon held by CIP. Available at: http://www.grain.org/bio-ipr/?id=335 (consulted 3 October 2008); ETC Group. 2001. Yacon come home? Available at: http://www.etcgroup.org/en/materials/publications.html?pub id=254 (consulted 4 October 2008). (In this case it transpired that CIP had transferred the material at the request of the Peruvian Ministry of Agriculture.)

${ }^{22}$ International Year of the Potato http://www.potato2008.org/en/index.html (consulted 3 October 2008)

${ }^{23}$ IIED. 2007. 'Insulted' Andean farmers pick GM potato fight with multinational Syngenta. Available at: http://www.iied.org/general/media/archive-media/insulted-andean-farmers-pick-gm-potato-fightwith-multinational-syngenta (consulted 3 October 2008)

${ }^{24}$ A. Argumedo and M. Pimbert. 2005. Traditional Resource Rights and Indigenous People in the Andes. London: IIED, p.10.

${ }^{25}$ Personal communication, 2007

${ }^{26} \mathrm{~S}$. Laird and R. Wynberg. Access and benefit-sharing in practice: trends in partnerships across sectors. CBD Technical Series 2008: p.128.

${ }^{27}$ Ibid, p. 122

${ }^{28}$ Ibid, p. 124

${ }^{29}$ CGIAR's annual admissions, for example, averaged 9782 for the five calendar years prior to the CBD, a figure which dropped to just 563 in 1997, with the drop in the number of collection missions being even sharper; W.P. Falcon and C. Fowler. Carving up the commons - emergence of a new international regime for germplasm development and transfer. Food Policy 2002; 27: 197-222.

${ }^{30}$ Anderson, op. cit. note 17

${ }^{31}$ C.M. Correa. Access to Genetic Resources and the FAO Treaty. The Case of Andean Countries. Journal of International Biotechnology Law 2004; 1: 153-155; M. Ruiz. 2003. The International Treaty on Plant Genetic Resources and Decision 391 of the Andean Community of Nations: Peru, The Andean Region and International Agricultural Research Centers. Lima, Peru: CIP \& SPDA. For example: The Dutch gene bank CGN, part of Wageningen UR, organised an expedition collecting wild potato varieties in Peru in 1999 - ie, after the CBD and the Andean Regime on Access to Genetic Resources came into force and before the ITPGR. The expedition was organised together with CIP, the Peruvian National Institute of Agrarian Research, and the National Research Support Program 6 of the US, and permission was granted by the Peruvian Ministry of Agriculture. It was agreed that all four partners would receive the same seed accessions. At the end of the expedition, however, a conflict had arisen between the Peruvian Ministries of Agriculture and the Environment about the export permission of the collected material. Due to the legal uncertainty this caused, CGN and its US partner decided to leave the country without the collected seeds, which were left behind. Now, almost 10 years later, the director of CGN, Dr. Visser, is still trying to get the accessions to the Netherlands: "Since Peru has ratified the Multilateral System of the FAO Treaty, which includes the potato, this should be legally possible but the practical circumstances are still uncertain" (personal communication, 2008). 
${ }^{32}$ J.P. Rosenthal and F. Katz. 2004. Natural products research partnerships with multiple objectives in global biodiversity hotspots: nine years of the ICBG Program. In Microbial diversity and bioprospecting. A.T. Bull, ed. Washington: ASM Press: 463.

${ }^{33}$ Ibid, p.465

${ }^{34}$ WIPO. 2005. Patent System and the Fight Against Biopiracy - the Peruvian Experience. WIPO/GRTKF/IC/8/12, p.3

${ }^{35}$ CIP, FEDECH. 2006. Catálogo de variedades de papa nativa de Huancavelica-Perú. Lima, Peru. CIP.

${ }^{36}$ Personal communication, 2007

${ }^{37}$ A. Argumedo and M. Pimbert. 2006. Protecting Indigenous Knowledge against Biopiracy in the Andes. London: IIED.

${ }^{38}$ GRAIN. 2005. ANDES-Potato Park-CIP agreement. Available at: http://www.grain.org/bioipr/?id=429 (consulted 03 October 2008). At present, CIP and most other CGIAR centres consider intellectual property issues mainly a defensive necessity. On the issue the director of CIP states: "Our primary objective here is to protect the physical and information assets that have been developed as global public goods and guarantee that they remain in the public domain" (Anderson, op. cit. note 17). But according to the conclusions of a CGIAR Science Council report, this approach no longer suffices. "In order to respond to the increasing needs for IPR guidelines, tools and services, the CGIAR should strengthen its overall capacity in these areas [...] Inaction is no longer an option." (CGIAR Science Council. 2006. CGIAR Research Strategies for IPG in a Context of IPR. Available at: http://www.sciencecouncil.cgiar.org/fileadmin/user_upload/sciencecouncil/Reports/IPR Report Web. pdf, p. 8). It still has to be seen what IP policy the CGIAR centres will eventually adopt and what consequences this will have for CIP's agreement with the Potato Park. For reasons of clarity and scope this debate on IPRs within the CGIAR, and on ABS issues at Wageningen UR, have not been included in this article.

${ }^{39}$ Wageningen UR. 2008. For Quality of Life. Wageningen, The Netherlands. p. 4

${ }^{40}$ Wageningen UR. 2007. Strategic Plan Wageningen UR 2007-2010. Wageningen: Netherlands.

${ }^{41}$ CSG, Wageningen UR. 2008. Sharing the benefits of biotechnology with developing countries. Conference: Wageningen, The Netherlands. 11 April 2008. Available at: http://www.societygenomics.nl/?page=582, Presentation by Prof. Stiekema.

${ }^{42}$ C. van Winden. 2007. Introduction: Variety innovation. In Netherlands catalogue of potato varieties. Netherlands Potato Consultative Foundation (NIVAP).

${ }^{43}$ TTI GG. http://www.groenegenetica.nl/prol/general/start.asp?t=about (consulted 4 October 2008)

${ }^{44}$ TTI GG. 2005. Innovative Plants for Sustainable Flowers and Food: TTI Green Genetics Business Plan. Wageningen, The Netherlands, p.12.

${ }^{45}$ TTI GG. 2007. Rules and Regulations With Respect to Industrial and Intellectual Property.

Wageningen, The Netherlands.

${ }^{46}$ Personal communication, 2008

${ }^{47}$ CBSG. No Date. CBSG Factsheet: Genomics for sustainable, high-quality potatoes. Wageningen, The Netherlands.

${ }^{48}$ M. Heselmans et al. 2008. Increasing access to biotechnology results: Report on the symposium 'Reconsidering Intellectual Property Policies (IPP) in public research'. Available at: http://www.society-genomics.nl/CSG_Downloads/doc_1738_FinalReport-11April2008.pdf (consulted 1 October 2008)

${ }^{49}$ NGI. http://www.genomics.n1/Valorisation/Valorisation\%20Strategy.aspx (consulted 3 October 2008)

${ }^{50}$ Personal communication, 2007

${ }^{51}$ Wageningen UR, op. cit. note 39, p.18.

${ }^{52}$ WBG. http://www.wbg.wur.nl/UK/ (consulted 3 October 2008), p.21

${ }^{53}$ CSG and Wageningen, op. cit. note 41, Presentation by Dr. Louwaars.

${ }^{54}$ Personal communication, 2007

${ }^{55}$ Y. Benkler. 2006. The wealth of networks: how social production transforms markets and freedom. New Haven, CT. Yale University Press, p. 340.

${ }^{56}$ G.E. Marchant. 2007. Genomics, ethics, and intellectual property. In Intellectual property management in health and agricultural innovation: a handbook of best practices, Volumes 1 and 2. A.M. Krattiger et al, eds. MIHR-USA: 29-38; A. Schonmann. From make believe to doomsday eve: Or should we patent genes? Medicine and Law 1998; 17: 455-476. 
${ }^{57}$ H. van den Belt. Forthcoming. Robert Merton, intellectual property, and open science: A sociological history for our times. In The commodification of academic research: analyses, assessments,

alternatives. H. Radder, ed. Pittsburg, PA: University of Pittsburgh Press; D. Rhoten and W.W. Powell. The frontiers of intellectual property: Expanded protection versus new models of open science. Annual Review of Law and Social Science 2007; 3: 345-373.

${ }^{58}$ A.D. So et al. Is Bayh-Dole Good for Developing Countries? Lessons from the US Experience. PLoS Biology 2008; 6: e262; S. Boettiger and A.B. Bennett. Bayh-Dole: if we knew then what we know now. Nature Biotechnology 2006; 24: 320-323; M.A. Heller and R.S. Eisenberg. Can Patents Deter Innovation? The Anticommons in Biomedical Research. Science 1998; 280: 698-701.

${ }^{59}$ R.C. Atkinson et al. Public sector collaboration for agricultural IP management. Science 2003; 301: 174-175, p.174.

${ }^{60}$ B. Koenders. 2008. Knowledge, Growth and Distribution: Strengthening the Capacity of Innovation Systems. Conference: The Hague, The Netherlands. 28 February 2008. Available at: http://www.nwo.nl/files.nsf/pages/NWOA 7E5DX8/\$file/Speech Koenders knowledge on the move .pdf, p.7

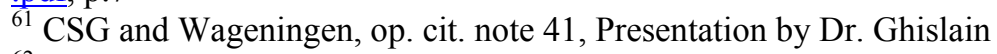

${ }^{62}$ M. Heselmans et al. 2008. Sharing biotechnology with developing countries: Start document for the symposium 'Reconsidering Intellectual Property Policies (IPP) in public research'. Available at: http://www.society-genomics.nl/uploads/media/IP-policies-Conference-11April2008-Startdoc.pdf (consulted 1 October 2008).

${ }^{63}$ CSG and Wageningen, op. cit. note 41, Panel discussion Prof. Kropff

${ }^{64}$ A. Pompidou. 2007. Letter from the President. In Scenarios for the Future: How might IP regimes evolve by 2025? What global legitimacy might such regimes have? European Patent Office: Munich, Germany: 3.

${ }^{65}$ IEGBIIP. 2008. Toward a New Era of Intellectual Property: From confrontation to negotiation.

Montreal, Canada, p.13.

${ }^{66}$ Ibid, p. 13

${ }^{67}$ Ibid, p. 8

${ }^{68}$ California Institute of Technology, et al. 2007. In the Public Interest: Nine Points to Consider in

Licensing University Technology. Available at: http://news-

service.stanford.edu/news/2007/march7/gifs/whitepaper.pdf

${ }^{69}$ PIPRA. http://www.pipra.org (consulted 3 October 2008)

${ }^{70}$ Personal communication, 2008

${ }^{71}$ Personal communication, 2007

72 PGSC. http://www.potatogenome.net/ (consulted 3 October 2008)

${ }^{73}$ Ibid

${ }^{74}$ M.W. Foster and R.R. Sharp. Share and share alike: deciding how to distribute the scientific and social benefits of genomic data. Nature Reviews Genetics 2007; 8: 633-639.

${ }^{75}$ Wellcome Trust. 2003. Sharing Data from Large-scale Biological Research Projects: A System of Tripartite Responsibility. Fort Lauderdale: USA, p.3.

${ }^{76}$ Ibid, p. 4, emphasis added

${ }^{77}$ Laird \& Wynberg, op. cit. note 26, p.130.

${ }^{78}$ Safrin, op. cit. note 4, p. 672.

${ }^{79}$ Safrin, op. cit. note 4. 